\title{
An Analysis of the Effectiveness of the Islamic Economic Movement: A Case Study of Mart 212 in Medan, Indonesia
}

\author{
Saparuddin Siregar ${ }^{1}$, M. Yasir Nasution ${ }^{2}$, Chuzaimah Batubara ${ }^{3}$, M. Ridwan ${ }^{4}$ and Sugianto $^{5}$ \\ \{saparuddin.siregar@uinsu.ac.id ${ }^{1}$, nasution_my@yahoo.com² ${ }^{2}$, chuzaimahbatubara@uinsu.ac.id ${ }^{3}$, \\ mridwanku@uinsu.ac.id ${ }^{4}$, sugianto@uinsu.ac.id $\left.{ }^{5}\right\}$ \\ 1,2,3,4,5 Universitas Islam Negeri Sumatera Utara, Medan Indonesia
}

\begin{abstract}
The people's economy movement is an effort made by Indonesian Muslims to increase the economic activities that emerged after the 212 Demonstration in Jakarta. This study aims to see the effectiveness of the establishment of Mart 212 as an effort to increase the economic activities and to transform the spirit of the unity of Muslims during the 212 Demonstration in Jakarta into real action. The results of this study are expected to become symbols that bind customers of rational and emotional markets. The sample of this research consists of six Mart 212 outlets in Medan, and 105 informants who are the investors and customers of Mart 212. The data were obtained through interviews and questionnaires and analysed by using qualitative descriptive method. The results show that the effort of increasing the economic activities through the establishment of Mart 212 is considered as a failure because it lacked emotional support from Muslims, and the management is unprofessional.
\end{abstract}

Keywords: Demo 212, Mart 212, rational customer, emotional customer, economic effort

\section{Introduction}

On December 2, 2016 there was a big scale demonstration known as "Demo 212" at the national monument (Monas) in Jakarta, Indonesia. This demonstration was claimed by the national movement of fatwa guards - Indonesian Ulema Council (Gerakan Nasional Pengawal Fatwa Majelis Ulama Indonesia/ GNPF - MUI) as the biggest demonstration ever because it was attended by 7 million people from all over Indonesia. This demonstration is considered bigger than the one taking place in 1998 (the overthrow of President Suharto). The 212 demonstration has united Indonesian Muslims who demand Ahok, the former governor of Jakarta province, to get severe punishment for his blasphemy on Islam.

After the 212 demonstration, some figures such as; Ichsanuddin Noorsy (Indonesian Economic Politics Analyst), Shafi'i Antonio (Islamic Finance and Banking Expert), and Ahmad Juwaini (Secretary General of World Zakah Forum) realized that demonstration is not enough to build political, economic, social and cultural power, but it has to be realized through systematic movements (Profil Koperasi Syariah 212 - Koperasi Syariah 212, no date). This idea, according to (Choiruzzad, 2013), falls into the category of "Islamic Economic Activities" which means as the efforts to organize individuals and groups to implement Islamic economy.

The realization of the spirit of 212 Demonstration on economy is the establishment of Mart 212 outlets in some areas Indonesia, including Medan, North Sumatra . This mart is the forerunner of Islamic economy whose functions to meet the household needs. 
Some figures of 212 Demonstration in Medan have initiated the establishment of Mart 212 outlets since June 2017. This establishment received enthusiastic welcome from Medanese Muslims. As a result, by the end of May 2018, six Mart 212 outlets have been established in Medan. Based on the Cooperation website of 212 (Profil Koperasi Syariah 212 - Koperasi Syariah 212, no date), it can be seen that there are 170 Mart 212 outlets throughout Indonesia.

The 212 Demonstration is a symbol of Islamic emotional spirit. If this symbol is projected through the establishment of Mart 212, it is strongly expected that it will be a powerful marketing tool to attract Muslim customers. However, from the observations made on some Mart 212 operating outlets, it reveals that there are only few customers who come to Mart 212. Besides, the products displayed are not as complete as the products displayed in existing mart outlets such as Indomart and Alfamart.

The gap between the enthusiasm to establish Mart 212 and the observation on the shopping activities has raised a question whether the spirit driving the people's economic movement is only limited to the establishment of Mart 212 alone or it will be effective to be developed rapidly on the following indicators; 1) good marketing strategies, and 2) the support of Muslims.

This study aims to see the effectiveness of the establishment of Mart 212 as an effort to increase the economic activities and to transform the spirit of the unity of Muslims during the 212 demonstration in Jakarta. The results of this study are expected to become symbols that bind customers of rational and emotional markets.

\section{Methodology}

This research applied qualitative research. The samples of this research were 6 outlets of Mart 212 in Medan. All of these outlets are managed by PT. Berkah Anak Negeri, shortened to Berani (Berani Ltd.) as the initiator of Mart 212 in Medan. These outlets are located in six different areas of Medan, namely: 1) Jl. Karya Jaya Medan Johor, 2) J1 Ar. Hakim Sukaramai, 3) Jl Pasar I Setia Budi, 4) Jl. STM, 5) Jl D.I Panjaitan dan 6) Jl. Bayangkara. There are two other outlets that are not included in the sample because they are managed separately by the local community and relatively new compared to the outlets managed by PT. Berani.

The respondents/informants of this study were the members of 212 community in Medan whose total number is 500 people coming from two groups: "telegram" and "whatsapp." Some members of this community became customers only while some others also take parts as investors. The questionnaires were distributed in July 2018, and they were delivered through social media groups. These questionnaires were also submitted to the respective shop leaders.

The research questions to the investors and customers include: 1) The number of shopping frequencies, 2) The total expenditure in rupiah for a month, 3) The assessment of service quality, and 4) The assessment on prices. The research questions to the shop leaders include: 1) Monthly income, 2) Inventory management, and 3) The reliability of human resources.

The assessment scale consists of four levels, for examples; level 1 (incomplete), level 2 (quite complete), level 3 (complete), and level 4 (very complete). This research is still in progress, and at this time, the data were only analysed by using descriptive statistics. In order to get more in-depth information, some critics and suggestions from respondents were also included in the questionnaires. The next process to be done is focus group discussion to the managers of Mart 212 including many more respondents of Mart 212 customers in Indonesia. 


\section{Result And Discussion}

Until the end of June 2018, there were six Mart 212 outlets in Medan managed by PT Berani, they are located in 1) Jl Karya Jaya Medan Johor, 2) Jl Ar. Hakim Sukaramai, 3) Jl Pasar I Setia Budi, 4) Jl. STM, 5) J1 D.I Panjaitan, and 6) Jl. Bhayangkara. The outlets that will be established soon are located in 1) Jl. Karya, 2) Jl. Garuda, and 3) Jl. Gaperta.

Setting up an outlet requires an average investment of IDR 500 million. This investment is offered to the 212 community, with a minimum participation of IDR 100 thousand and a maximum participation of IDR 2 million each person. In the establishment of the previous 6 outlets, the investment was made using social media (whatsapp). The supply can be met quickly within a matter of few hours. This indicated that Muslims have great ambition to support the economic activities through the establishment of Mart 212. However, in the establishment of the next three outlets, the investment rate is very slow, which may indicate that Medanese Muslims' motivation is low and it is strongly influenced by the effectiveness of the management of the previous Mart.

PT. Berani manages all of these outlets as the one who get the trust from the investors (the 212 community) with Mudharabah agreement. PT Berani, as the managing company, uses the investment funds to establish shop rentals, renovate, buy inventory, train the employees and buy supplies. Business progress in terms of sales and governance also under the responsibilities of PT Berani. PT Berani made an agreement to report the business development to the investors every month. This agreement is stated in SPKU (Surat Perjanjian Kerjasama Usaha/Letter of Business Cooperation Agreement). One of the SPKU items is an agreement from PT Berani to submit a financial report on the business development every month.

The critics and suggestions made by the respondents (the investors) are generally about the financial report which cannot be fulfilled as stated in the SPKU. Unfortunately, despite the existence of Mart 212, which has been running for a year, the management has not been able to submit the financial report as promised. One of the critics by Kurniawan (pseudonym) is as follows.

"The article 2 of the SPKU and the promises of the administrators delivered to the community/investors should be fulfilled. Otherwise, the investors will leave..."

"...Berjamaah-Amanah-Izzah, the one which is almost to be fulfilled is Berjamaah. This agreement needs someone trustworthy, not a smart person. But, it's better if the people are both trustworthy and knowledgeable to take care of ummah's funds."

Relevant to Kotler and Amstrong's theory, customer loyalty is influenced by the product, or $(\mathrm{P} /$ product $)$, the marketing component is mixed. Besides, it is also influenced by the service in the form of shopping convenience, staff hospitality, and speed.

The following responses were obtained from the 105 respondents of this study (54 investors and 51 customers):

The shopping frequency of $58 \%$ is still very low, it is two to four times a month (Table I). Furthermore, there are only 36,4 percent of respondents spending IDR 300.000,- or more every month (Table 2).

Table 1. The frequency of customer shopping every month

\begin{tabular}{|c|c|c|c|}
\hline No & Frequency & $\begin{array}{l}\text { The number of } \\
\text { respondents }\end{array}$ & Percentage \\
\hline 1 & Never & 3 people & $1 \%$ \\
\hline 2 & Once to twice a month & 61 people & $58,0 \%$ \\
\hline
\end{tabular}




\begin{tabular}{llll}
\hline 3 & $\begin{array}{l}\text { More than twice to four times a } \\
\text { month }\end{array}$ & 23 people & $21,9 \%$ \\
\hline 4 & More than four times & 18 people & $17,1 \%$ \\
\hline & The total & 105 people & $100,0 \%$ \\
\hline
\end{tabular}

Table 2. The amount of spending every month

\begin{tabular}{|c|c|c|c|}
\hline No & Frequency & $\begin{array}{l}\text { The number of } \\
\text { respondents }\end{array}$ & Percentage \\
\hline 1 & Less than IDR $100.000,-$ & 20 people & $20,2 \%$ \\
\hline 2 & $\begin{array}{l}\text { IDR } 100.000,- \text { to } \text { IDR } \\
200.000,-\end{array}$ & 28 people & $28,3 \%$ \\
\hline 3 & $\begin{array}{l}\text { IDR 200.000,- to IDR } \\
300,000,-\end{array}$ & 15 people & $15,2 \%$ \\
\hline \multirow[t]{2}{*}{4} & More than IDR 300.000,- & 36 people & $36,4 \%$ \\
\hline & The total & 99 people & $100,0 \%$ \\
\hline
\end{tabular}

In terms of prices, $57 \%$ of respondents (Table IV) considered "Quite competitive" compared to Indomart and Alfamart outlets. As many as $33 \%$ of respondents rated "Professional" services (Table V). However, the price and professional service are not enough to attract visitors to shop due to incomplete goods, as stated by $55 \%$ of visitors (Table 4 ).

Table 3. The completeness of the goods

\begin{tabular}{|c|c|c|c|}
\hline No & Frequency & $\begin{array}{l}\text { The number of } \\
\text { respondents }\end{array}$ & Percentage \\
\hline 1 & Not complete & 56 people & $55,0 \%$ \\
\hline 2 & $\begin{array}{l}\text { Complete } \\
\text { enough }\end{array}$ & 39 people & $35,0 \%$ \\
\hline 3 & Complete & 9 people & $9,0 \%$ \\
\hline 4 & $\begin{array}{l}\text { Very Complete } \\
\mathrm{e}\end{array}$ & 1 people & $1,0 \%$ \\
\hline & The total & 102 people & $100,0 \%$ \\
\hline
\end{tabular}

One of the dissatisfactions with the quality of the management of Mart 212 is outlined in the form of critics and suggestions by Omar (pseudonym) as an investor as follows:

"The items often run out many times even though the information for the shopping needs have been given"

The same comment was also given by Rasto (pesudonym) as follows:

"The stock of goods always runs out, especially for refill drinks and cup beverage drinks. This disappoints the consumers..."

Table 4. The price of goods compared to Indomart and Alfamart

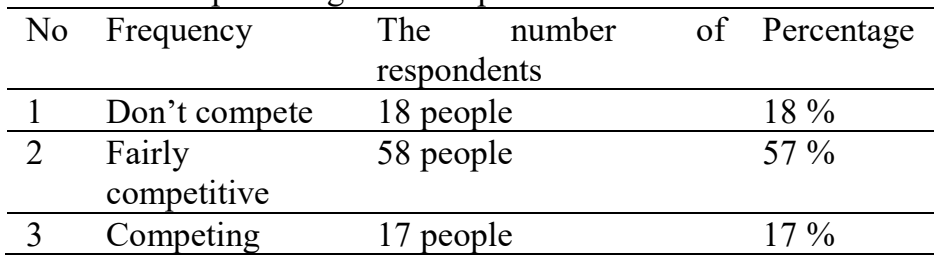




\begin{tabular}{llll}
\hline 4 & $\begin{array}{l}\text { Very } \\
\text { competitive }\end{array}$ & 9 people & $9 \%$ \\
\hline The total & 102 people & $100 \%$ \\
\hline
\end{tabular}

Table 5. Professional service and speed

\begin{tabular}{llll}
\hline No & Frequency & $\begin{array}{l}\text { The number } \\
\text { respondents }\end{array}$ & of \\
\hline 1 & Not professional & 6 people & $6 \%$ \\
\hline 2 & $\begin{array}{l}\text { Pretty } \\
\text { professional }\end{array}$ & 53 people & $52 \%$ \\
\hline 3 & Profesionals & 34 people & $33 \%$ \\
\hline 4 & $\begin{array}{l}\text { Very } \\
\text { Profesional }\end{array}$ & 9 people & $9 \%$ \\
\hline & The total & 102 people & $100 \%$ \\
\hline
\end{tabular}

In terms of service and hospitality, $53 \%$ of visitors considered the outlets to be professional. A comment from Omar as an investor is as follows:

" ... the management of the outlets 212 should be more creative and innovative in providing services to customers."

212 Mart outlets open from 07:00 a.m. to 10:00 p.m. Each outlet will stop its service for about 15 minutes by closing the service before the call to prayer and after the prayer. Based on the response given by the shop head, it shows that: 1) the average sales each day is only IDR 3 million to 5 million. The number of sales is still below the target in which it is expected that the minimum sales will be six to seven million each day; 2) if the amount of expenditure is going to IDR 5 million a day with the average amount of shopping is IDR 100 thousand, then the number of visitors a day is still in the range of 50 people.

The low number of shopping in Mart 212 has resulted in not achieving the sales target. The low shopping visit is due to incomplete products. The inability to complete this product is part of the failure of the mix marketing strategy.

Incomplete product becomes a major problem for marketing strategy, this cause the customers and investors do not maximize their spending. Thus, the customers and investors of Mart 212 are the rational customers who ignore the symbols of 212 Demonstration because their dissatisfaction overcomes their emotional side. The results of this study reinforce the findings of (Rini and Absah, 2017) which concluded that emotional marketing has no effect on customer loyalty. This research also answers the doubts of (Wilson and Grant, 2013) which state that Islamic symbols have not become the truth inherent in the actions of Muslims. The majority of visitors to outlet 212 is the rational visitors who attach importance to the completeness of goods (products) rather than just Islamic symbols. Thus, the spirit of 212 Action is still limited to the ability of gathering people physically but has not been able to turn into a shopping attitude that prioritizes Mart 212. This action still needs to improve its human resources, as what recommended by (Rusby and Hamzah, 2016).

\section{Conclusions}

This study is significant to fill the information gap about the relationship between the spirit of 212 Demonstration and the reality, and it is implemented on the economic activities. This study concludes that the spirit of 212 economic activities has not been effectively 
supported by the ability to manage which comes from the human resources, and it has not received the real support from customers of Mart 212.

This study contributes to the figures of 212 as a reference to the reality of emotional religious activities which were implemented by establishing Mart 212. This study recommends the need for further research for a wider sample and respondents; the outlets of Mart 212 in Indonesia.

\section{References}

[1] Choiruzzad, S. A. B. (2013) 'More Gain, More Pain: The Development of Indonesia's Islamic Economy Movement (1980s-2012)’, Indonesia, 5(95), pp. 125-172. Available at: https://doaj.org/article/8a96c24ec3764811ba1b62b4b3059871.

[2] Profil Koperasi Syariah 212 - Koperasi Syariah 212 (no date). Available at: http://koperasisyariah212.co.id/profil-koperasi-syariah-212/ (Accessed: 7 January 2019).

[3] Rini, E. S. and Absah, Y. (2017) 'Rational, emotional and spiritual marketing strategies in Shariah banking in Medan, Indonesia', Banks and Bank Systems, 12(2), pp. 68-77. doi: 10.21511/bbs.12(2).2017.07.

[4] Rusby, Z. and Hamzah, Z. (2016) 'Analisa Permasalahan Baitul Maal Wat Tamwil ( BMT ) melalui Pendekatan Analytical Network Process ( ANP )', Jurnal Al-hikmah, 13(1), pp. 18-29.

[5] Wilson, J. A. j. and Grant, J. (2013) 'Islamic marketing - a challenger to the classical marketing canon?', Journal of Islamic Marketing, 4(1), pp. 7-21. doi: $10.1108 / 17590831311306327$. 